\title{
SISTEM PENDUKUNG KEPUTUSAN DALAM PENENTUAN PENERIMA RASTRA (BERAS SEJAHTERA) MENGGUNAKAN METODE SIMPLE ADDITIVE WEIGHTING (STUDI KASUS DESA KARANG BANGUN)
}

\author{
Dicky Hartama Sinaga ${ }^{1}$, Heru Satria Tambunan², Jalaluddin³ \\ ${ }^{1}$ Mahasiswa Program Studi Sistem Informasi STIKOM Tunas Bangsa Pematang Siantar \\ 2,3 STIKOM Tunas Bangsa Pematangsiantar, Indonesia \\ Email: 1dicky.hartama@gmail.com, ${ }^{2}$ heru@amiktunasbangsa.ac.id, ${ }^{3}$ jalaluddin@amiktunasbangsa.ac.id
}

\begin{abstract}
Abstrak
Sistem Pendukung Keputusan (SPK) adalah sistem yang berbasis komputer yang menggabungkan model dan data dalam upaya memecahkan masalah tidak terstruktur dengan keterlibatan pengguna melalui antar muka pengguna yang mudah digunakan. Sistem ini digunakan untuk membantu pengambilan keputusan dalam situasi yang semiterstruktur dan situasi yang tidak terstruktur, dimana tak seorangpun tahu secara pasti bagaimana keputusan seharusnya dibuat. Metode Simple Additive Weighting adalah salah satu metode penyelesaian pada masalah Multi atributte decision making (MADM). Metode ini mengevaluasi beberapa alternatif terhadap sekumpulan atribut atau kriteria, dimana setiap atribut saling tidak bergantung satu dengan yang lainnya. Dari hasil penelitian menunjukkan pemanfaatan Metode Simple Additive Weighting sebagai model Sistem Pendukung Keputusan Kelayakan Penerimaan Bantuan Rastra (Beras Sejahtera) dengan metode weighted product di Desa Karang Bangun Kecamatan Siantar Kabupaten Simalungun dapat membantu pihak Desa dalam menghitung kelayakan calon penerima bantuan Beras dan untuk menentukan kelayakan penerima beras menjadi lebih cepat dan akurat. karena aplikasi ini lebih mudah dibandingkan sistem yang lama dan penyimpanan datanya lebih akurat.
\end{abstract}

Kata kunci: Sistem Pendukung Keputusan, Simple Additive Weighting, Rastra, Miskin

\begin{abstract}
Decision Support System (SPK) is a computer-based system that combines models and data in an effort to solve unstructured problems with user involvement through an easy-to-use user interface. This system is used to help decision making in semitructured situations and unstructured situations, where no one knows for sure how decisions should be made. Simple Additive Weighting method is one of the settlement methods for Multi attribute decision making (MADM) problems. This method evaluates several alternatives to a set of attributes or criteria, where each attribute does not depend on each other. Hope from the results of the study, the use of Simple Additive Weighting as a model of the Eligible Decision Support System for Rastra Assistance using the weighted product method in Karang Bangun Village, Siantar Subdistrict, Simalungun Regency can help the village in calculating the feasibility of rice recipients and to determine the eligibility of recipients of rice faster and more accurate. because this application is easier than the old system and the data storage is more accurate.
\end{abstract}

Keywords: Decision Support Systems, Simple Additive Weighting, Rastra, Poor

\section{PENDAhULUAN}

Di zaman globalisasi saat ini, pembangunan nasional sudah semakin ditingkatan. Hambatan salah satu pembangunan nasional ini yakni kemiskinan yang sampai sekarang belum bisa diberatas secara tuntas. Masalah kemiskinan nerupakan salah satu persoalan mendasar yang menjadi pusat perhatian pemerintah dinegara manapun termasuk negara kita Indonesia yang termasuk sebagai negara berkembang. Salah satu aspek penting untuk mendukung Strategi Penanggulangan Kemiskinan adalah tersedianya data kemiskinan yang akurat dan tepat sasaran. Pengukuran Kemiskinan yang dapat dipercaya dapat menjadi instrument tangguh bagi pengambil kebijakan dalam menfokuskan perhatian pada kondisi hidup orang miskin. Data kemiskinan yang akurat dapat digunakan untuk mengevaluasi kebijakan pemerintah terhadap kemiskinan, membandingkan kemiskinan antar waktu dan daerah, serta menentukan target penduduk miskin dengan tujuan untuk memperbaiki kondisi mereka.

Salah satu program Pemerintah yang digunakan untuk menanggulangi kemiskinan adalah Program Rastra (Beras Sejahtera) yaitu pembagian beras gratis yang jumlah kilonya sama kepada masyarakat miskin yang diselenggarakan oleh BULOG melalui pemerintah Desa. Rastra (Beras Sejahtera) merupakan salah satu upaya pemerintah untuk mengurangi beban pengeluaraan keluarga miskin. Yang berhak mendapatkan bantuan Rastra (Beras Sejahtera) adalah mereka yang memiliki persyaratan sebagai berikut : janda miskin yang mempunyai tiga orang anak, kepala keluarga yang berpenghasilan kurang dari satu juta rupiah perbulan, kepala keluarga tidak berpenghasilan tetap, rumah yang tidak layak huni. Pada saat ini kantor kelurahan masih menggunakan cara manual yaitu pemilihan penerima Bantuan Rastra (Beras Sejahtera) dengan cara mengumpulkan data warga yang tergolong miskin dari tiap-tiap dusun dan memusyawarahkannya lagi untuk memilih warga yang paling berhak sesuai dengan jumlah kuota bantuan yang tersedia. Secara umum permasalahan yang terjadi pada bantuan pemberian Rastra (Beras Sejahtera) masih belum optimal, banyak terjadi kendala dalam pemberian bantuan seperti kesalahan dalam menginput data warga sehingga dalam pemberian Rastra (Beras Sejahtera) sedikit atau banyaknya warga terkadang protes karena warga yang seharusnya berhak mendapatkan bantuan tetapi mereka tidak dapat, begitu juga sebaliknya warga yang seharusnya tidak berhak malah mendapatkan bantuan Rastra (Beras Sejahtera) tersebut.

Untuk dapat menyeleksi warga mana yang berhak atas Rastra (Beras Sejahtera) tersebut, maka diperlukan sistem yang terkomputerisasi untuk membantu pihak kelurahan dalam pengambilan keputusan untuk menentukan warga 
mana yang berhak untuk mendapatkan rastra tersebut. Terdapat beberapa cara dalam menentukan alternatif tersebut, salah satu contohnya adalah dengan menggunakan sistem pakar yang merupakan suatu sistem yang menghasilkan suatu informasi yang pasti. Salah satu cara yang digunakan dalam sistem pendukung keputusan adalah logika fuzzy. Algoritma yang digunakan dinamakan Fuzzy Multiple Attribute Decision Making (FMADM). Dalam algoritma FMADM ini terdapat bemacam metode yang digunakan untuk membantu dalam permasalahan yang ada, salah satu metodenya adalah metode Simple Additive Weighting.

Salah satu peelitian yang terkait dengan penelitian ini yaitu Penelitian yang di lakukan oleh [1] yang berjudul "Sistem Pendukung Keputusan Menentukan Calon Penerima Raskin Menggunakan Metode Simple Additive Weighting." Penelitian ini bertujuan untuk membuat klasifikasi warga calon penerima Raskin menggunakan Algoritma Metode Simple Additive Weighting, yang menghasilkan 7 kriteria yang dapat dijadikan sebagai acuan untuk menentukan warga Calon Penerima Raskin dari penerapan metode Simple Additive Weighting tersebut. Dalam analisa ini, seluruh data yang diperoleh calon penerima beras raskin akan di implementasikan berdasarkan metode fuzzy SAW yang digunakan. Berikut ini kriteria-kriteria yang digunakan pekerjaan, penghasilan, jumlah tanggungan, luas bangunan rumah, kondisi rumah, sinetasi rumah, dan aliran listrik.

Metode Simple Additive Weighting ini diharapkan bisa membantu dalam penyeleksian calon penerima beras pada warga miskin di Desa Karang Bangun, metode Simple Additive Weighting ini cukup dapat menyelesaikan masalah tersebut. Metode ini mencari alternatif yang terbaik dari banyak alternatif yang ada dengan cara memberikan bobot setiap kriteria untuk alternatif tersebut. Alternatif tersebut adalah warga miskin yang menjadi calon penerima bantuan.

\section{TEORITIS}

\subsection{Sistem Pendukung Keputusan}

Sistem pendukung keputusan adalah suatu sistem informasi spesifik yang ditujukan untuk membantu manajemen dalam mengambil keputusan yang berkaitan dengan persoalan yang bersifat[2][3]:

1. Terstruktur, yaitu berhubungan dengan persoalan yang telah diketahui sebelumnya dengan penyelesaian standar aturan yang telah ditentukan.

2. Semi terstruktur, yaitu berhubungan dengan persoalan yang belum diketahui sebelumnya, dengan parameter yang sudah ada.

3. Tidak terstruktur, yaitu berhubungan dengan persoalan baru yang cukup pelik, karena banyaknya data yang belum diketahui.

Tahap-tahap dalam proses pengambilan keputusan yaitu [4][5]:

1. Tahap Penelusuran (Intellegence) Tahap ini merupakan proses penelusuran, pendeteksian dari lingkup problematika serta proses pengenalan masalah. Data yang diperoleh diproses dan diuji dalam rangka mengidentifikasikan masalah.

2. Tahap Perancangan (Design) Tahap ini merupakan proses menemukan, mengembangkan dan menganalisis tindakan yang mungkin dilakukan. Hal ini meliputi pemahaman terhadap masalah dan menguji solusi yang layak.

3. Tahap Pemilihan (Choice) Pada tahap dibuat suatu keputusan yang nyata dan diambil suatu komitmen untuk mengikuti suatu tindakan tertentu.

4. Tahap Implementasi (Implementation) Pada tahap ini dibuat suatu solusi yang direkomendasikan dapat bekerja atau implementasi solusi yang diusulkan untuk suatu masalah.

\subsection{Simple Additive Weighting Method (SAW)}

Simple Additive Weighting Method (SAW) sering juga dikenal dengan metode penjumlahan terbobot. Konsep dasar metode SAW, adalah mencari penjumlahan terbobot dari rating kinerja pada setiap alternatif dari semua atribut, metode SAW membutuhkan proses normalisasi matrik keputusan (x) ke suatu skala yang dapat diperbandingkan dengan dengan semua rating alternatif yang ada[6].

Langkah Penyelesaian Metode SAW adalah sebagai berikut :

1. Menentukan alternatif, yaitu Ai.

2. Menentukan kriteria yang akan dijadikan acuan dalam pengambilan keputusan, yaitu $\mathrm{Cj}$.

3. Memberikan nilai rating kecocokan setiap alternatif pada setiap kriteria.

4. Menentukan bobot preferensi atau tingkat kepentingan (W) setiap kriteria

$$
\mathrm{W}=\left[\begin{array}{lllll}
w_{1} & w_{2} & w_{3} & \cdots & w_{j}
\end{array}\right]
$$

5. Membuat tabel rating kecocokan dari setiap alternatif pada setiap kriteria.

6. Membuat matrik keputusan X yang dibentuk dari tabel rating kecocokan dari setiap alternatif pada setiap kriteria. Nilai $x$ setiap alternatif (Ai) pada setiap criteria $(\mathrm{Cj})$ yang sudah ditentukan, dimana, $\mathrm{i}=1,2, \ldots \mathrm{m}$ dan $\mathrm{j}=1,2, \ldots \mathrm{n}$.

$X=\left[\begin{array}{cccc}x_{11} & x_{12} & \ldots & x_{1 j} \\ x_{i 2} & x_{i 2} & \ldots & x_{i j}\end{array}\right]$ 
7. Melakukan normalisasi matrik keputusan dengan cara menghitung nilai rating kinerja ternomalisasi (rij) dari alternatif Ai pada kriteria $\mathrm{Cj}$.

$r_{i j}=\left\{\begin{array}{l}\frac{x_{i j}}{\max _{i}\left(x_{i j}\right)} \\ \frac{\max _{i}\left(x_{i j}\right)}{x_{i j}}\end{array}\right.$

Jika $\mathrm{j}$ adalah kriteria keuntungan (benefit)

Jika j adalah kriteria biaya (cost)

Keterangan :

a. Dikatakan kriteria keuntungan apabila nilai xij memberikan keuntungan bagi pengambil keputusan, sebaliknya kriteria biaya apabila xij menimbulkan biaya bagi pengambil keputusan.

b. Apabila berupa kriteria keuntungan maka nilai xij dibagi dengan nilai Maxi(xij) dari setiap kolom, sedangkan untuk kriteria biaya, nilai Mini (xij) dari setiap kolom dibagi dengan nilai xij.

8. Hasil dari nilai rating kinerja ternomalisasi (rij) membentuk matrik ternormalisasi (R)

$$
R=\left[\begin{array}{ccccc}
r_{11} & & r_{11} & \ldots & r_{1 j} \\
& \vdots & & & \vdots \\
r_{i 1} & & r_{11} & \ldots & r_{1 j}
\end{array}\right]
$$

9. Hasil akhir nilai preferensi (Vi) diperoleh dari penjumlahan dari perkalian elemen baris matrik ternormalisasi (R) dengan bobot preferensi (W) yang bersesuaian eleman kolom matrik (W).

$V_{i}=\sum_{j=1}^{n} w_{j} r_{i j}$

\section{ANALISA DAN PEMBAHASAN}

\subsection{Analisis Data}

Dalam melakukan atau mendapatkan data, penulis menggunakan metode pengumpulan data yaitu metode sampling dan metode populasi. Dalam skripsi ini penulis mengumpulkan datanya menggunakan metode sampling, yaitu mengambil sebagian data untuk diteliti. Dalam metode penelitian ini ada kriteria yang dibutuhkan untuk menentukan siapa yang akan terseleksi sebagai calon penerima Rastra mengacu pada Pedoman Umum Subsidi Rastra yang dikeluarkan oleh Kementrian Koordinator Bidang Pembangunan Manusia dan Kebudyaan pada tahun 2017. Adapun kriterianya adalah :

C1 = Jumlah Anggota Keluarga

C2 = Adanya Balita / Anak Sekolah

C3 = Lansia / Kepala Keluarga Perempuan (Janda)

C4 = Kondisi Rumah

C5 = Penghasilan

Dari masing-masing bobot tersebut, maka dibuat suatu variable. Dimana dari suatu variable tersebut akan dirubah kedalam bilangan fuzzy, metode ini dipilih karena mampu menyeleksi alternatif terbaik dari sejumlah alternatif. Dibawah ini adalah bilangan fuzzy dari bobot dengan pendekatan subyektif :

$1=$ Sangat Rendah $(\mathrm{SR})$

$2=$ Rendah $(\mathrm{R})$

$3=$ Sedang $(\mathrm{S})$

4 = Tinggi $(\mathrm{T})$

$5=$ Sangat Tinggi $(\mathrm{ST})$

1. Seleksi Jumlah Anggota Keluarga (C1)

Tabel 1. Sub Kriteria C1

\begin{tabular}{ccc}
\hline C1 & Nilai & Keterangan \\
\hline$<=3$ & 1 & Sangat Rendah \\
4 & 2 & Rendah \\
5 & 3 & Sedang \\
6 & 4 & Tinggi \\
$>=7$ & 5 & Sangat Tinggi \\
\hline
\end{tabular}

2. Adanya Balita / Anak Sekolah (C2)

Tabel 2. Sub Kriteria C2

\begin{tabular}{lcc}
\hline \multicolumn{1}{c}{ C2 } & Nilai & Keterangan \\
\hline Tidak Memiliki & 1 & Sangat Rendah \\
Memiliki Balita & 2 & Rendah \\
Memiliki Anak Sekolah & 3 & Sedang \\
Memiliki Balita dan Anak Sekolah & 4 & Tinggi \\
\hline
\end{tabular}

3. Lansia / Janda (C3)

Tabel 3. Sub Kriteria C3 
4. Kondisi Rumah

5. Penghasilan

\begin{tabular}{lcc}
\hline \multicolumn{1}{c}{ C3 } & Nilai & Keterangan \\
\hline Normal & 1 & Santat Rendah \\
Lansia & 2 & Rendah \\
Janda & 3 & Sedang \\
Lansia dan Janda & 5 & Sangat Tinggi \\
\hline
\end{tabular}

\section{Tabel 4. Sub Kriteria C4}

\begin{tabular}{lcc}
\hline \multicolumn{1}{c}{ C4 } & Nilai & Keterangan \\
\hline Pribadi - Permanen & 1 & Santat Rendah \\
Pribadi - Semi Permanen & 2 & Rendah \\
Kontrak - Permanen & 3 & Sedang \\
Pribadi - Non Permanen & 4 & Tinggi \\
Kontrak - Non Permanen & 5 & Sangat Tinggi \\
\hline
\end{tabular}

Tabel 5. Sub Kriteria C5

\begin{tabular}{lcc}
\hline \multicolumn{1}{c}{ C5 } & Nilai & Keterangan \\
\hline$>4.000 .000$ & 1 & Santat Rendah \\
$2.000 .000-<4.000 .000$ & 2 & Rendah \\
$1.000 .000-<2.000 .000$ & 3 & Sedang \\
$500.000-<1.000 .000$ & 4 & Tinggi \\
$<500.000$ & 5 & Sangat Tinggi \\
\hline
\end{tabular}

\subsection{Perhitungan Metode Simple Additive Weighting (SAW)}

Pada bagian pembahasan ini dijelaskan secara umum bagaimana cara menghitung dengan menggunakan metode Simple Addictive Weighting (SAW). Dalam melakukan perhitungan manual penulis menggunakan 5 sampel data Alternatif calon penerima Bantuan Rastra (Beras Sejahtera).

Tabel 6. Sampel Warga Calon penerima bantuan

\begin{tabular}{|c|c|c|c|c|c|c|}
\hline No & Nama & $\begin{array}{c}\text { Jumlah } \\
\text { Anggota } \\
\text { Keluarga }\end{array}$ & $\begin{array}{c}\text { Adanya Balita/Anak } \\
\text { Sekolah }\end{array}$ & $\begin{array}{c}\text { Lansia / } \\
\text { Janda }\end{array}$ & Kondisi Rumah & Penghasilan \\
\hline 1 & $\begin{array}{l}\text { Muhammad } \\
\text { Prayendra Lubis }\end{array}$ & 5 & $\begin{array}{l}\text { Memiliki Anak } \\
\text { Sekolah }\end{array}$ & Normal & Pribadi - Permanen & 2.500 .000 \\
\hline 2 & Harfianto & 7 & $\begin{array}{l}\text { Memiliki Balita dan } \\
\text { Anak Sekolah }\end{array}$ & Normal & Kontrak - Permanen & 2.800 .000 \\
\hline 3 & Boinah & 2 & Tidak Memiliki & $\begin{array}{l}\text { Lansia dan } \\
\text { Janda }\end{array}$ & Pribadi - Semi Permanen & 600.000 \\
\hline 4 & Eza Satria & 4 & Memiliki Balita & Normal & Kontrak - Non Permanen & 1.800 .000 \\
\hline 5 & Mayrudi & 4 & $\begin{array}{l}\text { Memiliki Anak } \\
\text { Sekolah }\end{array}$ & Lansia & Pribadi - Semi Permanen & 3.000 .000 \\
\hline
\end{tabular}

1. Membuat Matriks Keputusan X

Berdasarkan data awal alternatif dari ke-9 penerima bantuan Rastra (Beras Sejahtera) pada tabel 6 diatas dapat dibentuk suatu matriks keputusan $X$ yang menunjukkan ranking kecocokan dari setiap alternatif pada setiap kriteria adalah sebagai berikut :

Tabel 7. Ranking Kecocokan dari Setiap Alternatif Calon Penerima Bantuan

\begin{tabular}{clccccc}
\hline No & \multicolumn{1}{c}{ Nama } & $\begin{array}{c}\text { Jumlah Anggota Adanya Balita/Anak } \\
\text { Keluarga }\end{array}$ & Sekolah & Lansia/Janda & Kondisi Rumah Penghasilan \\
\hline 1 & Muhammad Prayendra Lubis & 3 & 3 & 1 & 1 & 2 \\
2 & Harfianto & 5 & 4 & 1 & 3 & 2 \\
3 & Boinah & 1 & 1 & 5 & 2 & 4 \\
4 & Eza Satria & 2 & 2 & 1 & 5 & 3 \\
5 & Mayrudi & 2 & 3 & 2 & 2 & 2 \\
\hline
\end{tabular}

Dari tabel alternatif diatas maka dapat dibentuklah sebuah matriks keputusan $\mathrm{X}$ adalah sebagai berikut :

$$
X=\left\{\begin{array}{lllll}
3 & 3 & 1 & 1 & 2 \\
5 & 4 & 1 & 3 & 2 \\
1 & 1 & 5 & 2 & 4 \\
2 & 2 & 1 & 5 & 3 \\
2 & 3 & 2 & 2 & 2
\end{array}\right\}
$$

2. Menetapkan bobot Kriteria 
Pembuat keputusan telah menentukan bobot kriteria atau bobot preferensi adalah sebagai berikut :

Tabel 8. Bobot Setiap Kriteria

\begin{tabular}{clc}
\hline Atribut & \multicolumn{1}{c}{ Kriteria } & Bobot \\
\hline C1 & Jumlah Anggota Keluarga & 20 \\
C2 & Adanya Balita / Anak Sekolah & 20 \\
C3 & Lansia / Kepala Keluarga Perempuan (Janda) & 20 \\
C4 & Kondisi Rumah & 10 \\
C5 & Penghasilan & 30 \\
\hline
\end{tabular}

3. Melakukan proses normalisasi

Setelah itu, langkah ketiga adalah proses normalisasi matriks x berdasarkan persamaan(3) berikut :

$$
\begin{aligned}
& r 1.1=\frac{3}{\max \{3 ; 5 ; 1 ; 2 ; 2\}}=\frac{3}{5}=0,6 \\
& r 2.1=\frac{5}{\max \{3 ; 5 ; 1 ; 2 ; 2\}}=\frac{5}{5}=1 \\
& r 3.1=\frac{1}{\max \{3 ; 5 ; 1 ; 2 ; 2\}}=\frac{1}{5}=0,2 \\
& r 4.1=\frac{2}{\max \{3 ; 5 ; 1 ; 2 ; 2\}}=\frac{2}{5}=0,4 \\
& r 5.1=\frac{2}{\max \{3 ; 5 ; 1 ; 2 ; 2\}}=\frac{2}{5}=0,4
\end{aligned}
$$

4. Membuat Matriks Normalisasi

Kemudian langkah selanjutnya adalah membuat matriks normalisasi dari proses normalisasi diatas yaitu :

$$
R=\left\{\begin{array}{ccccc}
0,6 & 0,75 & 0,2 & 0,2 & 0,5 \\
1 & 1 & 0,2 & 0,6 & 0,5 \\
0,2 & 0,25 & 1 & 0,4 & 1 \\
0,4 & 0,5 & 0,2 & 1 & 0,75 \\
0,4 & 0,75 & 0,4 & 0,4 & 0,5
\end{array}\right\}
$$

5. Menghitung nilai preferensi alternatif terbaik

Langkah kelima adalah membuat perhitungan matrik $\mathrm{W} * \mathrm{R}$ yaitu :

$$
\begin{aligned}
\mathrm{A} 1 & =(20 * 0,6)+(20 * 0,75)+(20 * 0,2)+(10 * 0,2)+(30 * 0,5) \\
& =12+15+4+2+15 \\
& =48
\end{aligned}
$$

$$
\begin{aligned}
\mathrm{A} 2 & =(20 * 1)+(20 * 1)+(20 * 0,2)+(10 * 0,6)+(30 * 0,5) \\
& =20+20+4+6+15 \\
& =65 \\
\mathrm{~A} 3 & =(20 * 0,2)+(20 * 0,25)+(20 * 1)+(10 * 0,4)+(30 * 1) \\
& =4+5+20+4+30 \\
& =63
\end{aligned}
$$

$$
\begin{aligned}
\mathrm{A} 4 & =(20 * 1)+(10 * 0,5)+(20 * 1)+(10 * 0,8)+(30 * 1) \\
& =8+10+4+10+22,5 \\
& =54,5 \\
\mathrm{~A} 5 & =(20 * 0,4)+(20 * 0,75)+(20 * 0,4)+(10 * 0,4)+(30 * 0,5) \\
& =8+15+8+4+15 \\
& =50
\end{aligned}
$$

6. Proses Perangkingan

Langkah terakhir adalah proses perangkingan. Adapun proses perangkingan dari sampel calon penerima bantuan adalah sebagai berikut:

Tabel 9. Hasil Perangkingan metode SAW

\begin{tabular}{clc}
\hline Alternatif & \multicolumn{1}{c}{ Nama } & Nilai SAW \\
\hline A1 & Muhammad Prayendra Lubis & 48,00 \\
A2 & Harfianto & 65,00 \\
A3 & Boinah & 63,00 \\
A4 & Eza Satria & 54,50 \\
A5 & Mayrudi & 50,00 \\
\hline
\end{tabular}

Maka urutan alternatif yang memiliki nilai kriteria tertinggi dan bisa dipilih adalah : 

a. A2/Harfianto $=65$
b. A3/Boinah $=63$
c. A4/Eza Satria $=54,5$
d. A4/Mayrudi $=50$
e. A1/Mahammad Prayendra Lubis $=48$

\subsection{Pemrosesan (Process) Sistem}

Pemrosesesan akan menampilkan hasil keseluruhan dari proses Simple Addictive Weighting (SAW). Pada Form ini tidak ada proses penginputan data. Proses ini akan melakukan perhitungan otomatis sesuai dengan nilai kriteria dan bobot yang dimasukkan oleh pengguna. Form ini menamplkan beberapa perhitungan otomatis seperti matriks keputusan $\mathrm{X}$ dan nilai normalisasi.

1. Tampilan Matriks Keputusan X

Form ini untuk menampilkan matriks keputusan $\mathrm{X}$ yang menunjukkan ranking kecocokan dari setiap alternatif pada setiap kriteria yang telah diinput. Tampilan matriks keputasan $\mathrm{X}$ dilihat pada gambar 1 dibawah ini.

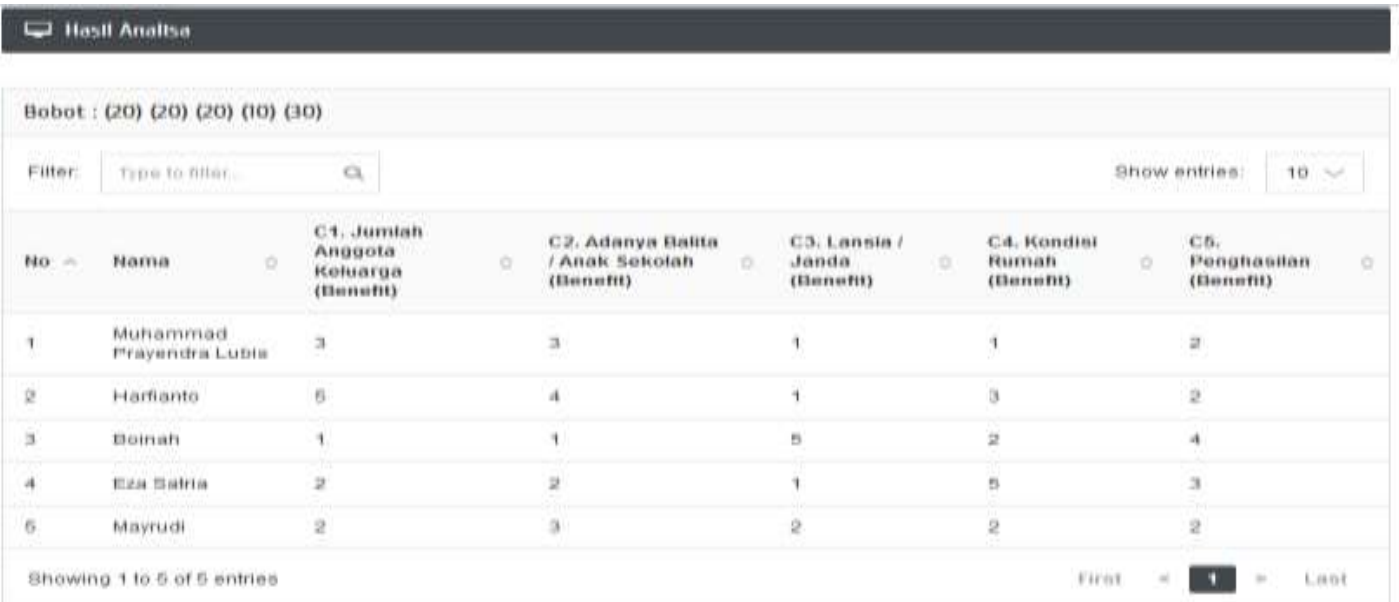

Gambar 1. Tampilan Matriks Keputusan X

2. Tampilan data normalisasi

Tampilan Form ini menampilkan hasil normalisasi data dari matrik keputusan X. Tampilan data normalisasi dapat dilihat pada gambar 2 dibawah ini.

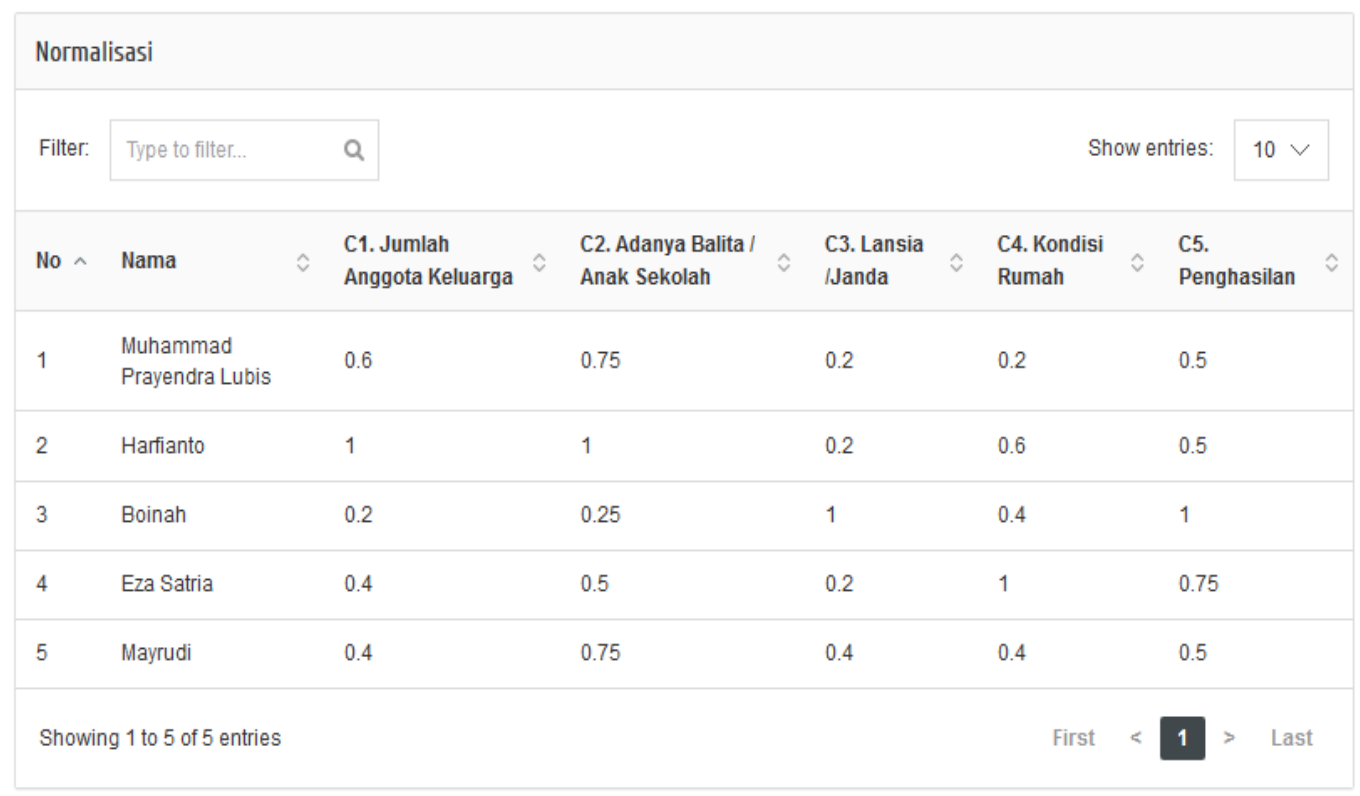

Gambar 2. Tampilan Data Normalisasi 


\subsection{Keluaran (Output) Sistem}

Pada bagian ini menampilkan hasil output dari sistem. Adapun tampilan keluaran atau output dapat dilihat pada gambar 3 dibawah ini.

\begin{tabular}{|c|c|c|c|c|c|}
\hline \multicolumn{6}{|c|}{ Perangkingan } \\
\hline Filter: & Tive bo filer. & $Q$ & \multicolumn{2}{|r|}{ Show entries: } & $10 v$ \\
\hline No & a & Hama & $\hat{z}$ & Nisai & $\theta$ \\
\hline 1 & & Wuhammad Prayendra Lubis & & 48 & \\
\hline 2 & & Hafiante & & 65 & \\
\hline 3 & & Boinah & & 63 & \\
\hline 4 & & Era Satia & & 545 & \\
\hline 5 & & Mannud & & 50 & \\
\hline \multicolumn{3}{|c|}{ Shoxing 1 to 5 of 5 entries } & First & $t<1$ & Last: \\
\hline
\end{tabular}

Gambar 3. Tampilan Output Hasil Perangkingan

Dari hasil perhitungan yang telah dilakukan oleh sistem terdapat hasil nilai yang bisa dijadikan rekomendasi untuk menentukan penerima bantuan Rastra (Beras Sejahtera) dari 5 (lima) data sampel penelitian yang dilakukan. Urutan rekomendasi warga dari yang paling layak ke yang tidak menerima bantuan adalah sebagai berikut :

1. A2/Harfianto $=65$

2. A3/Boinah $=63$

3. A4/Eza Satria $=54,5$

4. A4/Mayrudi $=50$

5. A1/Mahammad Prayendra Lubis $=48$

Proses perhitungan ini sama dengan hasil perhitungan manual yang dilakukan dengan menggunakan metode Simple Addictive Weighting (SAW).

\section{KESIMPULAN}

Berdasarkan hasil penelitian dan analisa yang telah dilakukan oleh penulis, dan juga penjelasan Laporan Skripsi yang telah diuraikan pada bab sebelumnya mengenai "Sistem Pendukung Keputusan Dalam Penentuan Penerima Rastra (Beras Sejahtera) Menggunakan Metode Simple Additive Weighting (Studi Kasus Desa Karang Bangun)” yaitu $: 1.7$

\section{REFERENCES}

[1] G. Yanti, K. Sari, S. Pahu, L. R. Putri, And R. Renaldo, "Sistem Pendukung Keputusan Menentukan Calon Penerima Raskin Menggunakan Metode Simple Additive Weighting,” J. Teknoinfo, Vol. 12, No. 2, Pp. 82-86, 2018.

[2] T. Imandasari And A. P. Windarto, "Sistem Pendukung Keputusan Dalam Merekomendasikan Unit Terbaik Di Pdam Tirta Lihou Menggunakan Metode Promethee,” J. Teknol. Dan Sist. Komput., Vol. 5, No. 4, P. 159, 2017.

[3] K. Fatmawati, A. P. Windarto, And M. R. Lubis, "Analisa Spk Dengan Metode Ahp Dalam Menentukan Faktor Konsumen Dalam Melakukan Kredit Barang,” Vol. I, Pp. 314-321, 2017.

[4] T. H. Prasetyo, "Model Promethee Ii Untuk Sistem Pendukung Keputusan Provinsi Sulawesi Barat,” Pp. 6-7, 2016.

[5] D. R. Sari, A. P. Windarto, D. Hartama, And S. Solikhun, "Sistem Pendukung Keputusan Untuk Rekomendasi Kelulusan Sidang Skripsi Menggunakan Metode Ahp-Topsis,” J. Teknol. Dan Sist. Komput., Vol. 6, No. 1, P. 1, 2018.

[6] T. I. M. Safii, "Rekomendasi Benih Tomat Terbaik Menggunakan Metode Simple Additive Weighting,” No. 1. 